\title{
An Analysis of English Language Education (ELE) Students' Motivation in Learning Pedagogical Courses
}

\author{
Putu Yoga Sathya Pratama*, I Gusti Ayu Lokita Purnamika Utami, \\ Luh Diah Surya Adnyani \\ Program Studi Pendidikan Bahasa Inggris, Universitas Pendidikan Ganesha, Singaraja, Indonesia \\ E-mail: yoga.sathya.pratama@undiksha.ac.id, lokitapurnamika@undiksha.ac.id, surya.adnyani@undiksha.ac.id
}

\begin{abstract}
Previous studies on motivation had been broadly researched, but little attention was given to learning pedagogical courses motivation. Thus, this qualitative research with case-study research design was conducted. This research aimed to describe ELE students' motivation in learning pedagogical courses. The data were collected by using questionnaire, interview guidance, and human instrument. The obtained data were analyzed qualitatively through interactive data analysis. The result portrays that there are more ELE students tend to be intrinsically motivated in learning pedagogical courses; the rest are identified to be extrinsically motivated, unmotivated, and undefined motivated students. The reasons underlying their motivation in learning pedagogical courses can be categorized into: 1) internal reasons (mood, goals, passion, perspective, \& personality) and 2) external reasons (parent, score, and lecturer).
\end{abstract}

Keywords: Motivation; Pedagogical Courses; ELE

\section{Introduction}

Pendidikan Bahasa Inggris or English Language Education (ELE) is one of education departments in Ganesha University of Education (Undiksha). It is located in Singaraja, Bali, Indonesia. Since this department focuses on education field, the major courses learned during studying in ELE are pedagogical courses. Pedagogical course is a course that focuses on the education, such as the knowledge of education; syllabus; theory of teaching; approaches, methods, and techniques of teaching; assessment; and many more (Katarina Aškerc Veniger, 2016). As the major courses learned by ELE students, pedagogical courses are learned intensively from the first until the last semester. Based on Buku Pedoman Mahasiswa ELE or ELE students' guidebook 2016, KKNI (Kerangka Kualifikasi Nasional Indonesia)-based curriculum, there are several pedagogical courses learned by ELE students in their study, namely: 1) PPD (Perkembangan Peserta Didik) or Educational Psychology, 2) Wawasan Kependidikan or Knowledge of Education, 3) Belajar dan Pembelajaran or Learning and Instruction, 4) Classroom Management, 5) Telaah Kurikulum or Curriculum and Material Development, 6) Strategi dan Design Pembelajaran or Learning Strategies and Design, 7) Asesmen dan Evaluasi Pembelajaran or Learning Assessment and Evaluation, 8) TEFL (Teaching English as a Foreign Language), 9) Pembelajaran Mikro or Micro Teaching, 10) Material Development in ELT, 11) TEYL (Teaching English for Young Learners), and 12) PPL (Program Pengalaman Lapangan) or Practice Teaching.

Pedagogical course is a major course enrolled by university students, especially students of education department, because it prepares them to be a professional teacher in certain discipline (Parylo, 2015). In line with that statement, a pre-survey was conducted on June 12, 2019, to see whether ELE students have a desire to be a teacher or not. The result portrayed that there was an inclination that almost half of ELE students do not want to be a teacher. This result can be interpreted that not all ELE students wanted to be a teacher, even though their department is an education department that prepares them to be a professional teacher. Furthermore, the pre-survey result created such a big question, especially on students' motivation in learning pedagogical courses as the major courses.

\footnotetext{
${ }^{*}$ Corresponding author.

Received 18 February 2020; Accepted 20 March 2020; Available online 31 March 2020 (C) 2020 JPI. All Rights Reserved
} 
Knowing how learner's learning motivation is very useful for educators in designing, running, and making judgment in accordance with their motivation (Andreas, 2019). The context of motivation in this research denotes to Self-Determination Theory (SDT) proposed by Decy \& Ryan (2000). Decy \& Ryan (2000) mentioned that motivation is someone's impetus or initiator for doing something. SDT provides 3 basic human innate needs which consist of competence, relatedness, and autonomy. First, competence is related to feeling of confident and effective in mastering whatever we are doing, such as the outcome and the experience mastery. Second, relatedness is related to feeling of being cared, connected, and sense of belonging with others. Third, autonomy is related to having choices and to feeling of freedom in controlling over own actions. Decy \& Ryan (2000) believe that no matter the culture and origin, everyone certainly has these needs dimensions. When all innate needs dimensions can affiliate and meet each other, it would drive someone to be more intrinsically motivated, but if cannot, it would drive someone to be more extrinsically motivated or even unmotivated (Decy \& Ryan, 2000).

In one of its sub-theory; organismic integration theory (OIT); SDT classifies human motivation into 3 types: 1) amotivation, 2) extrinsic motivation, and 3) intrinsic motivation. First, the amotivation refers to the circumstance where someone has no motivation at all toward a particular activity. Amotivation is portrayed through: 1) having no action or just going through the motions, 2) rebelling, 3) not feeling relatedness, 4) not expecting anything. Second, the extrinsic motivation refers to the circumstance where someone is motivated because of external factors. Extrinsic motivation is portrayed through: 1) influenced by rewards, 2) underlined by avoiding guilt or anxiety and improving pride, 3) accepting the activity even though experience lack of enjoyment or importance, and 4) feeling the importance but not getting interested. Third, the intrinsic motivation refers to the circumstance where someone is motivated because of internal factors. Intrinsic motivation is portrayed through: 1) feeling enjoyable in doing the activity, 2) really interested in doing the activity, 3) valuing the activity, and 4) more self-regulated.

Indeed, there are enormous researches on motivation in learning $(\mathrm{Hu}$, Jia, Plucker, \& Shan, 2016; Lin, Chen, \& Liu, 2017; Tsai, Cheng, Yeh, \& Lin, 2017; Salikin, Bin-Tahir, Kusumaningputri, \& Yuliandari, 2017; Yulika, Rahman, \& Sewang, 2019; and ZarzyckaPiskorz, 2016). Numerous researchers around motivation consider that this is an interesting variable to be investigated. However, around aforementioned researches, little attention is given to the scope of learning pedagogical course motivation. Several researches that closely related to this research are: 1) attitude of learning pedagogical courses (Parylo, $2015), 2$ ) opinion and perception about learning pedagogical courses (Katarina Aškerc Veniger, 2016; Katarina Aškerc \& Sebastian Kočar, 2017; and Pekkarinen \& Hirsto, 2017), 3) the use of technology in pedagogical courses (Chin, Hong, Huang, Shen, \& Lin, 2016; and Keçeci \& Zengin, 2017), and 4) the effect of learning pedagogical courses (Ödalen et al., 2018).

Deriving from the previous narratives, this research attempted to describe ELE students' learning motivation in learning pedagogical courses. It is urgent because of several reasons, namely: 1) there is limited information about the topic of motivation in learning pedagogical courses, and 2) the result of the pre-survey to the ELE Students of Undiksha showed such big questions on their learning motivation in learning pedagogical courses as their major courses. In order to answer these questions, this research further attempted to 1) describe ELE students' motivation in learning pedagogical courses and 2) investigate reasons underlying ELE students' motivation in learning pedagogical courses. The grounded theory used was Decy \& Ryan (2000) Self-Determination Theory (SDT). The research's novelty is proposed to 1) gain data about motivation, especially in the area of pedagogical courses and 2) answer the questions appeared from the conducted pre-survey.

\section{Method}

This research was a qualitative research with case-study research design. The research was conducted in English Language Education (ELE) of Undiksha on OctoberDecember 2019. The participants were 199 fifth semester students of ELE Undiksha in 
academic year 2019/2020. The instrument used in obtaining the data were an online questionnaire and an interview guidance. The questionnaire consisted of 36 numbers of statements related to Decy \& Ryan (2000) types of motivation contained in SelfDetermination Theory (SDT): Amotivation, Extrinsic Motivation, and Intrinsic Motivation. The questionnaire was made on a five-point Likert scale, which was ranged from 1 (Strongly Disagree) until 5 (Strongly Agree). In addition, there were also 2 open-ended questions that were related to how the students assess their motivation in learning pedagogical courses and how they see the pedagogical courses learning in ELE, Undiksha. The interview guidance was made after the questionnaire result was obtained. The interview contained 20 students who represented each motivation types (undefined motivation, unmotivated, extrinsically motivated, \& intrinsically motivated). The obtained data were analyzed qualitatively through Miles \& Huberman (1994).

\section{Finding and Discussion}

This research discovered 2 main findings: 1) there is an inclination showing that most of observed ELE students are identified to be intrinsically motivated in learning pedagogical courses, while the rest are identified to be extrinsically motivated, unmotivated, and undefined motivated; 2) the reasons underlying ELE students' motivation in learning pedagogical courses can be categorized into 2 categories, they are internal reasons (mood, goals, passion, perspective, \& personality) and external reasons ( parent, score, \& lecturer). The first research finding was obtained through the online questionnaire and the second research finding was obtained through the interview that was conducted by the researcher as the human instrument. First of all, based on the questionnaire result, ELE students' motivation in learning pedagogical courses can be classified into 4 categories: 1) undefined motivated, 2) unmotivated, 3) extrinsically motivated, and 4) intrinsically motivated. It can be seen through table 1, as follow:

Table 1. Summary of Students' Motivation Type

\begin{tabular}{ccc}
\hline Motivation type & Total & Percentages \\
\hline Undefined Motivation & 8 & $4 \%$ \\
\hline Unmotivated & 9 & $5 \%$ \\
\hline Extrinsically Motivated & 28 & $14 \%$ \\
\hline Intrinsically Motivated & 154 & $77 \%$ \\
\hline
\end{tabular}

The questionnaire results portrayed a tendency that there are more ELE students who are intrinsically motivated in learning pedagogical courses than the students who are unmotivated, extrinsically motivated, and even undefined motivated. It can be interpreted that there are more students who enjoy and feel the importance of pedagogical courses learning in ELE, Undiksha. It is proven by the participants' answer in the open-ended questions, where there are most students have positive perception toward pedagogical courses learning in ELE Undiksha. Hence, it seems to be acceptable to discover most ELE students tend to be intrinsically motivated in learning pedagogical courses. In addition, the first finding of this research is in line with the result of Ödalen et al. (2018), where they found that there are more participants (7 of 10 participants) in Sweden tended to be more motivated because they feel satisfied in joining the pedagogical training.

Additionally, the first research finding also displayed an interesting result of undefined motivation. Although the percentage of undefined motivation students is insignificant, it is such a great discovery to the field of motivation theory. The result of undefined motivation portrays that there is also individual who cannot determine their definite motivation. It is not about motivated or unmotivated again, but it refers to an individual's indescribable condition. This research attempts to propose that someone's motivation further can be classified into amotivation, extrinsic motivation, intrinsic motivation, and undefined motivation. This research also tries to argue that since Decy \& Ryan's Self-Determination Theory does not mention about the circumstance of undefined motivation, this theory is not that absolute and exclusive in classifying someone's motivation. 
The context of undefined motivation is justified by Kaufmann, Schulze, \& Veit (2011). Kaufmann, et al. (2011) investigated mechanical worker in Turk motivation since various researches related to their motivation were not grounded on recognized motivation theory. Simply, there is no current motivational theories match with their motivation. Kaufmann, et al. (2011) further discovered that the terms behind their subject were beyond the motivation aspects, they were immediate payoffs, delayed payoffs, social motivation, task autonomy, and skill variety. These aspects were found as the influential factors underlying their work and their persistent. Kaufmann, et al. (2011) strengthen that undefined situation on someone's motivation does exist, even though it seems that it is not mentioned yet in any motivation theories. In addition, Uno (2006) stated that everyone has their own theme underlying their motivation; motivation further becomes a broad variable to be discussed. The theories of motivation will always develop along with the continued discovery of interesting things related to motivation. As an inference, the discovery of undefined motivation is such a new reference to enrich the data and information around motivation.

Second of all, the second research finding was obtained through the interview results. There were 8 major identified reasons underlying ELE students' motivation in learning pedagogical courses: 1) mood, 2) goals, 3) passion, 4) perspective, 5) personality, 6) parent, 7) score, \& 8) lecturer. These reasons were further categorized into internal reasons (mood, goals, passion, perspective \& personality) and external reasons (parent, score, and lecturer). Even though there were several reasons that underlie same motivation type, but basically each motivation was showing different form of reason underlying their motivation in learning pedagogical courses. In addition, different motivation types also have different narrations related to the dimensions of competence, relatedness, and autonomy. It would be presented in table 2.

Table 2. Reasons underlying ELE students' motivation in learning pedagogical courses

\begin{tabular}{|c|c|c|}
\hline No. & Motivation Type & Reason Underlying the Motivation \\
\hline \multirow[t]{2}{*}{1.} & Undefined Motivation & 1) Mood influence \\
\hline & & 2) The absence of definite goals \\
\hline \multirow[t]{4}{*}{2.} & Unmotivated & 1) The absence of passion in educational field \\
\hline & & 2) Parental influence \\
\hline & & 3) Passing the courses as ultimate goal \\
\hline & & $\begin{array}{l}\text { 4) The absence of relationship between learning } \\
\text { pedagogical courses and dream job }\end{array}$ \\
\hline \multirow[t]{5}{*}{3.} & Extrinsically Motivated & 1) The absence of passion in educational field \\
\hline & & 2) Parental influence \\
\hline & & 3) Lecturer influence \\
\hline & & 4) Score influence \\
\hline & & 5) Non-educational benefit of learning pedagogical \\
\hline \multirow[t]{4}{*}{4.} & Intrinsically Motivated & 1) Positive value of teacher profession \\
\hline & & 2) Positive perspective of pedagogical courses learning \\
\hline & & 3) Excitement in learning \\
\hline & & 4) Definite goals \\
\hline
\end{tabular}

First, the context of competence, relatedness, and also autonomy in undefined motivation becomes further undefined too. Mood is not an autonomy factor since it is somehow uncontrollable. It does not also belong to competence because mood does not represent the idea of mastering the thing confidently. Additionally, the total absence of definite goals also seems to have no affiliation in each dimension. Second, in the context of unmotivated students; no competence is shown by passing the courses as the ultimate goals and the absence of relationship between learning pedagogical courses and dream job. Those reasons indicate that the unmotivated students do not have an impetus to outcome and experience mastery in learning pedagogical courses. No relatedness is shown by no passion in educational field. It drives the observed unmotivated students do not feel the sense of belonging during the process of learning. No autonomy is clearly shown by parental 
influence, because it indicates that the observed unmotivated students do not have feeling of freedom in choosing the department, they are passionate with.

Third, in the context of extrinsically motivated students; the reasons of score influence and lecturer influence denote to no competence. It is because the observed extrinsically motivated students only focus on maintaining their pride, without concerning about experience mastery. The reason of the absence of passion in education field clearly refers to no relatedness. In the dimension of autonomy, there is a contrast between parental influence and non-educational benefit of learning pedagogical courses. Parental influence underlines that observed extrinsically motivated students do not have feeling of freedom in choosing their option, but non-educational benefit of learning pedagogical courses shows they have full authority to choose what they want to learn in pedagogical courses learning. Fourth, in the context of intrinsically motivated students, competence is shown by positive value of teacher profession and positive perspective of pedagogical courses learning. It is because these reasons indicate that the observed intrinsically motivated students feel confident during the learning activity as well as concern of the future beneficial outcome. Relatedness is shown by excitement in learning. This reason indicates that the sense of belonging and connecting which makes them feel excitement in learning. The autonomy is indicated by the reason of definite goals. The observed intrinsically motivated students have full control of the actions in a purpose to reach their goals or objectives, such as searching for more learning sources, studying longer than the others, and always coming to the class meeting.

By the narrations above, it can be concluded that the finding of reasons underlying ELE students' motivation in learning pedagogical courses in this research and the idea of competence, relatedness, and autonomy is justified. All findings are in line with the Decy \& Ryan's statements. It is also such a triangulation data of the first and the second research finding, where different motivation has different form of innate needs dimension. The reasons presented in table 2 further were synthesized into 2 categories, namely internal reasons (mood, goals, passion, perspective, \& personality) and external reasons (parent, score, \& lecturer). Each category is being discussed, as follow.

The first internal reason being discussed is mood influence. In this case, mood influence underlies the observed undefined motivated participants only. The interview had figured out that when the undefined motivated students were in a good mood, they would tend to be intrinsically motivated in learning. Meanwhile, they would tend to be extrinsically motivated or even unmotivated in learning when they were not in a good mood. It could be interpreted that their motivation inclined to be often transformed based on the mood condition.

This finding is in line with Chiew \& Braver (2011) and Ekici (2011). They researched about how mood or emotion facilitates motivation. As the result, their observed subjects tend to regulate their motivation when they feel positive emotions, in which it denotes to a good mood circumstance. Ekici (2011) added the negative emotional subjects incline to lose the purpose of the things they are doing. In addition, the finding of mood influence in this case is supported by Løvoll, Røysamb, \& Vittersø (2017), who propose that the positive emotions also form an indicator of continuity in doing something. Løvoll, et al. (2017) mentioned that when positive emotions are well maintained, it will turn the emotion into an intrinsic motivation. Løvoll, et al. (2017) strengthen the tendency of undefined motivated students to be intrinsically motivated when they are in a good mood and Ekici (2011) strengthens the tendency of undefined motivated students to be extrinsically motivated or unmotivated when they are not in a good mood. Taking into account, these narrations prove the inclination that mood or emotion underlies someone to be motivated or not as well as changes the circumstances of their motivation.

The second internal reason being discussed is goals influence. Goals or objectives influence underlies all motivation types. Yet, the interpretation of the goal itself is different in each motivation type. The undefined motivated students tend to have no definite goals, the unmotivated students tend to merely pass the courses, the extrinsically motivated students tend to just follow the courses but hoping for good score, and the intrinsically motivated students tend to set definite goals they wanted to reach. This finding indeed is in line with the 
characteristics of each motivation type cited in Decy \& Ryan's (2000) self-determination theory.

Different from other motivation types, undefined motivation's characteristics are not mentioned in self-determination theory. The finding of their underlying reason around goals aspect is the absence of the definite goal. When it is compared to the goal-oriented theory, Mc. Donald (1959) for instance, this finding is possible to occur in context of undefined motivation because literary they are blurry about themselves. As their motivation is often changed, where it depends on mood, their goal cannot be definitely determined either. Mc. Donald's (1959) goal-oriented theory proposed that "motivation is a respond to what do you what to reach", in which it denotes to the goal itself. Hence, since the undefined motivation does not have the objective to be reached, it becomes an accepted thing for the undefined motivated students of this research to have no definite goals in learning pedagogical courses.

Another supporting foundation for this finding arises from Elliott \& Story (2017). Charles N. Elliott is an influential figure of goal-oriented theory. Elliott \& Story (2017) proposed that goal orientation can be distinguished into mastery goals and performance goals. On one hand, the mastery goals have a positive relationship with the intrinsic motivation. The context of mastery goals aims to master the content being worked and receive a positive feedback for the better improvement. On the other hand, the performance goals have a positive correlation with the extrinsic motivation. The context of performance goals denotes to result of a work. Taking a look into the finding of this research, the extrinsically motivated students' goal of this research is just following the courses activity and hoping for a good score or result. The intrinsically motivated students' goal of this research is more certain, which is able to comprehend or master the content of pedagogical courses as well as be able to apply the knowledge of pedagogical courses for the future. Compared the finding of this research to Elliott \& Story (2017), we will see that this finding is in line with Elliott \& Story (2017) theory.

The third internal reason being discussed is passion influence. In this case, the discussion will be limited into the framework of no passion in education, as the result of the unmotivated and the extrinsically motivated students of this research. The undefined and also intrinsically motivated students do not mention about the context of passion. Hence, it will be only counted as the unmotivated and the extrinsically motivated reason underlying their motivation in leaning pedagogical courses. The unmotivated as well as the extrinsically motivated participants honestly mentioned that their different passion from education becomes a strong influential reason underlying their motivation in learning pedagogical courses. This finding is in line with Greenwald \& Blackmore (2017), Stoeber, Childs, Hayward, \& Feast (2011), and Vallerand (2012).

Motivation and Passion are often debated because these terms tend to be identic. While motivation describes an imitator or impetus for doing something, passion denotes to a strong predisposition toward what you loved (Vallerand, 2012). In addition, Vallerand (2012) mentioned that a passionate person feels the essential as well as the meaningfulness of doing the activity. Vallerand (2012) gives an example about tennis player. When you play tennis every day, it most refers to motivation because you may not love it. Yet, if you play tennis every time, buy any things related to tennis, watch almost all tennis tournament, and the most important thing that you never feel harmed; then these denote to passion.

In the context of self-determination theory, the idea of "love" and "meaningfulness" in passion tend to appear in the context of intrinsic motivation. Meanwhile, the amotivation and the extrinsically motivation do not feel the sense of love and meaningful itself. Hence, since their passion is not in education field, it is a justification for them to be not classified with intrinsic motivation in learning pedagogical courses itself. This finding is in line with Stoeber, Childs, Hayward, \& Feast (2011) and Greenwald \& Blackmore (2017). They found that the participant who is putted in a different circumstance from his or her passion tends to have less motivation even somehow no motivation at all. Stoeber, et al. (2011) also proposed that the final outcome of impassionate person is not satisfying as the consequence of doing something without the sense of love. Thus, these narrations prove that the finding of passion 
influence that found in unmotivated and extrinsically motivated participants can be acknowledged.

The fourth internal reason being discussed is perspective influence. Perspective or perception influence is mentioned by the observed unmotivated, extrinsically motivated, and intrinsically motivated students of this research. First, the observed unmotivated students tend to see no relationship at all between learning pedagogical courses and their dream job. Second, the observed extrinsically motivated students tend to see non-educational benefit of learning pedagogical courses. Third, the observed intrinsically motivated students tend to have positive perspective toward teacher profession as well as learning pedagogical courses for their future. Hence, each of them mentions different perspective underlying their motivation.

The idea of perspective in this finding is in line with the self-determination theory by Decy \& Ryan (2000). Decy \& Ryan (2000) mentioned that the amotivation does not value and give any credit toward the activity. Meanwhile, the extrinsic motivation gives several attentions but rather for another context. Different from the previous motivation types, the intrinsic motivation highly values the activity as well as gives more credits toward every part of the activity. Hence, it is an acceptable discovery that the unmotivated students see no relationship at all, the extrinsically motivated students see benefit for other contexts, and the intrinsically motivated students have positive perspective toward the pedagogical courses learning as well as toward the teacher profession. Additionally, this finding is also supported by Sailer, Hense, Mandl, \& Klevers (2014), who mentioned that different motivations tend to have different perspectives that drive them into the continuity and also resilient in doing a particular activity.

The fifth as well as the last internal reason being discussed is personality influence. Personality appears as the reason underlying observed intrinsically motivated students. In this case, it is believed that all observed participants are also influenced by their personality. Yet, during the interview section, only the intrinsically motivated students show tendency of this influencer. It is indicated by the eager learner personality. The observed intrinsically motivated students incline to love studying, have high curiosity toward new knowledge, like challenges, and be autonomous learners.

The idea of eager learner personality is implicitly cited in the self-determination theory. Decy \& Ryan (2000) proposed that the intrinsic motivation tend to be more selfregulated. The self-regulated in Decy \& Ryan (2000) proposition denotes to set a clear objective, do something in a long period without feeling hampered, find any sources to enrich their comprehension, and engage in every related activity. These statements are indeed in line with the personality of the observed intrinsically motivated students of this research. In addition, it is explicitly mentioned by Ariani (2013) that intrinsic motivation has positive relationship toward openness to experience, conscientiousness, extraversion, and agreeableness personality. These indicators proposed by Ariani (2013) refers to The Big Five Theory, a personality theory that divides human's personality into OCEAN; O for Openness, $\mathrm{C}$ for Conscientiousness, E for Extraversion, A for Agreeableness, and $\mathrm{N}$ for Neuroticism.

As what Ariani (2013) mentioned, the intrinsic motivation is more referred to openness to experience, which means that they had high curiosity and interest toward new things. The conscientiousness personality denotes that intrinsically motivated person has inclination to work carefully and structurally. The extraversion, famous for "extrovert" term, means that the intrinsically motivated person is easier to interact and socialize in community. The agreeableness reflects easy to forgive and help. Compared to the finding of this research, it shows such a consistency where the observed intrinsically motivated students of the research tend to love learning, have high curiosity toward new knowledge, and like challenges, which denote to "openness to experience". The autonomous learned further denoted to "Conscientiousness".

Move into the external factors of this case; the first external reason being discussed is parental influence. This reason is mentioned by unmotivated and extrinsically motivated students of this research. What can be inferred from the interview result is that these 2 motivation types tend to be powerless against their parents' desire. As the unmotivated and 
extrinsically motivated students have no passion in education; studying pedagogical courses in education department is literary to just fulfill their parents' desire. This is another key term why these motivation types aim to just follow the game during learning pedagogical courses. Their principle is "their parents' happiness is their happiness either". Moreover, their parents' desire is such an order to be followed for them.

The idea of parental influence is in line with the basic motivation' characteristics that proposes in self-determination theory, especially for the extrinsically motivated students. As the theory mentions that extrinsic motivation is influenced by external factors, this finding shows one of that external factors is parental influence. The parental influence forces them to survive in the impassion circumstance. The surprising finding is that the characteristic of amotivation in Decy \& Ryan's self-determination theory does not mention about outside factor influence, as in this case is parental influence. Decy \& Ryan (2000) even mentioned there is a high possibility of amotivation to drop out themselves. Yet, as well as the extrinsically motivated students of this research, the unmotivated participants present that they can maintain their less-motivation to survive in this circumstance because of parental influence.

The finding of parental influence on motivation has been broadly discussed, such as by Christenson, Wylie, \& Reschly (2012) and Gonida \& Urdan (2007). Talking about parental issues, there are many variables which are needed to be considered, such as family's economy, culture, perception, etc. (Christenson, et al., 2012). Compared to the finding of this research, the parental influence occurs because participants' parents of this research perceive that English has broad opportunity where their children can work in various sectors. As mentioned by Gonida \& Urdan (2007), the children further become powerless against their parents because of several reasons, namely 1) desire to gratify the family, 2) responsibility to reimburse the family's sacrifices, 3) perception of family's strong support toward academic achievement, 4) perception of lifting up family's pride, and 5) perception of academic performance. In this case, these factors are positively connected with the finding of the research, which is shown by the participants who aim to make their parents happy as that was their happiness too.

The second external reason being discussed is lecturer influence. This finding is only mentioned by the extrinsically motivated students of this research. Indeed, there are 3 external factors that influence the extrinsically motivated students of this research: 1) parental influence, 2) lecturer influence, and 3) score influence. Besides the parental influence, the lecturer influence and score influence are the reasons which are not mentioned by other motivation types except extrinsically motivation. Interview result shows that the way lecturer taught the observed extrinsically motivated students will determine their behavior in learning. If they think it is match with them, they tend to follow the class nicely. However, if they perceive the lecturer cannot teach them well, they incline to ignore the class activity.

In the context of pedagogical courses in university, this finding is reliable with Katarina Aškerc \& Sebastian Kočar (2017). In 2016, Katarina Aškerc Veniger found that most Slovenian teachers feel unsatisfied when joining Pedagogical Courses Training (PCT). It is indeed such an interesting case, knowing that even the teachers who have learned pedagogical courses tend to have no motivation in pedagogical courses training. Further research has been conducted by Katarina Aškerc \& Sebastian Kočar (2017). Surprisingly, they found that the trainer or the instructor in that program cannot teach them well. Even, $34 \%$ of the instructors never learn pedagogical courses before. The impact is that the participants cannot regulate their motivation while joining that pedagogical courses program. Taking into account, as portrayed by Katarina Aškerc Veniger (2016) and Katarina Aškerc \& Sebastian Kočar (2017), the finding of this research shows that lecturer has strong influence toward students' motivation.

The third as well as the last external reason being discussed is score influence. This reason is another outside factor that exposed by the extrinsically motivated students of this research. Compared to other motivation types, the extrinsic motivation is the only motivation type that is underlain by this reason. Score is the external factor that is used to boost the observed extrinsically motivated students to study. The interview shows that the observed 
extrinsically motivated students tend to study hard if only the activity is being assessed. This is in line with the statement of Elliott \& Story (2017) that extrinsic motivation's goals are more inclined towards results and performance than inclined toward comprehending and being able to apply. In this case, getting high score is the consequence of maintaining their pride toward friends, lecturers, and their parents. This is also in line with the characteristic of the extrinsic motivation proposed by Decy \& Ryan (2000), that extrinsic motivation is identic with doing something for avoiding negative feeling toward the social circumstance.

\section{Conclusion and Suggestion}

Due to the limitation and unavailability of the researcher to figure out motivation in all semesters, the presented results are not conclusive. However, these results portray that this case does exist in English Language Education (ELE) of Undiksha. Furthermore, the results of this research can be used as one of references to conduct future researches in a same area which are more rigorous and conclusive. The finding and discussion of this case portray that: 1) there is an inclination showing that most of observed ELE students are identified to be intrinsically motivated in learning pedagogical courses, while the rest are identified to be extrinsically motivated, unmotivated, and undefined motivated, and 2) reasons underlying ELE students' motivation in learning pedagogical courses can be categorized into 2 categories, they are internal reasons (mood, goals, passion, perspective, \& personality) and external reasons (parent, score, \& lecturer). The research's results are expected to be used by the department and the lecturer as a reference and evaluation material. By using the results of this research, the department as well as the lecturers can program the most suitable approaches, methods, techniques, and strategies to teach the students based on their particular motivation.

\section{References}

Andres, H. P. (2019). Active teaching to manage course difficulty and learning motivation. Journal of Further and Higher Education, 43(2), 220-235. https://doi.org/10.1080/0309877X.2017.1357073

Ariani, D. W. (2013). Personality and Learning Motivation. European Journal of Business and Management, 5(10), 26-38. https://doi.org/10.4324/9781315588391-5

Chin, K. Y., Hong, Z. W., Huang, Y. M., Shen, W. W., \& Lin, J. M. (2016). Courseware development with animated pedagogical agents in learning system to improve learning motivation. Interactive Learning Environments, 24(3), 360-381. https://doi.org/10.1080/10494820.2013.851089

Chiew, K. S., \& Braver, T. S. (2011). Positive affect versus reward: Emotional and motivational influences on cognitive control. Frontiers in Psychology, 2(OCT), 1-10. https://doi.org/10.3389/fpsyg.2011.00279

Christenson, S. L., Wylie, C., \& Reschly, A. L. (2012). Parental Influences on Achievement Motivation and Student Engagement. Handbook of Research on Student Engagement, 1-840. https://doi.org/10.1007/978-1-4614-2018-7

Deci, E. L., \& Ryan, R. M. (2000). Intrinsic Motivation and Extrinsic Motivation: Classic Definitions and New Directions. Contemporary Educational Psychology, 25, 54-67. https://doi.org/10.1006/ceps.1999.1020

Deci, E. L., \& Ryan, R. M. (2008). Self-Determination Theory: A Macrotheory of Human Motivation, Development, and Health. Canadian Psychology, 49(3), 182-185. https://doi.org/10.1037/a0012801

Deci, E. L., \& Ryan, R. M. (2015). Self-Determination Theory. International Encyclopedia of Social \& Behavioral Sciences (Second Edition, Vol. 11). Elsevier. https://doi.org/10.1016/B978-0-08-097086-8.26036-4

Ekici, S. (2011). The effect of positive and negative mood on motivation to succeed of elite athletes. International Journal of Human Sciences, 8(2), 946-962.

Elliott, C. N., \& Story, P. A. (2017). Motivational Effects of Goal Orientation. The Kennesaw Journal of Undergraduate Research, 5(1), Article 4. https://doi.org/10.32727/25.2019.18 
Gonida, E. N., \& Urdan, T. (2007). Parental influences on student motivation, affect and academic behaviour: Introduction to the Special Issue. European Journal of Psychology of Education, 22(1), 3-6. https://doi.org/10.1007/BF03173685

Greenwald, R., \& Blackmore, C. (2017). Passion Play: The Relationship between Passion and Motivation in On-Line Gaming. SOJ Psychology, 5(1), 1-4. https://doi.org/10.15226/2374-6874/5/1/00142

Hu, W., Jia, X., Plucker, J. A., \& Shan, X. (2016). Effects of a Critical Thinking Skills Program on the Learning Motivation of Primary School Students. Roeper Review, 38(2), 70-83. https://doi.org/10.1080/02783193.2016.1150374

Kaufmann, N., Schulze, T., \& Veit, D. (2011). More than fun and money. Worker Motivation in

Crowdsourcing - A Study on Mechanical Turk. Proceedings of the Seventeenth Americas Conference on Information Systems, 4(2009), 1-11. https://doi.org/10.1145/1979742.1979593

Katarina Aškerc Veniger. (2016). University Teachers' Opinions about Higher Education Pedagogical Training Courses in Slovenia. C E P S Journal. 6, 141-161.

Katarina Aškerc \& Sebastian Kočar. (2017). Teaching and the Pedagogical Training of University Teaching Staff - Practice and Opinions under Slovenian Higher Education Legislation. Education Inquiry. ISSN:4508(February). https://doi.org/10.3402/edui.v6.25591

Keçeci, G., \& Zengin, F. K. (2017). Observing the Technological Pedagogical and Content Knowledge Levels of Science Teacher Candidates. Educational Research and Reviews, 12(24), 1178-1187. Retrieved from http://ezproxy.lib.uconn.edu/login?url=https://search.ebscohost.com/login.aspx?direct=t rue \&db=eric\&AN=EJ1164648\&site=ehost-live

Li, P., \& Pan, G. (2009). The Relationship between Motivation and Achievement-A Survey of the Study Motivation of English Majors in Qingdao Agricultural University. English Language Teaching, 2(1), 123-128. https://doi.org/10.5539/elt.v2n1p123

Lin, M. H., Chen, H. C., \& Liu, K. S. (2017). A study of the effects of digital learning on learning

motivation and learning outcome. Eurasia Journal of Mathematics, Science and Technology Education, 13(7), 3553-3564. https://doi.org/10.12973/eurasia.2017.00744a

Løvoll, H. S., Røysamb, E., \& Vittersø, J. (2017). Experiences matter: Positive emotions facilitate intrinsic motivation. Cogent Psychology, 4(1). https://doi.org/10.1080/23311908.2017.1340083

Mc. Donald, Frederick. (1959). Educational Physchology. Tokyo: Wadsworth Publishing Company.

Miles, Mattew B. \& Huberman, A. Michael. (1994). Qualitative Data Analysis. United States of America: Sage Publication.

Ödalen, J., Brommesson, D., Erlingsson, G. Ó., Karlsson, J., Fogelgren, M., Ödalen, Karlsson,

J. (2018). Teaching university teachers to become better teachers: the effects of pedagogical training courses at six Swedish universities. Higher Education Research \& Development, 0(0), 1-15. https://doi.org/10.1080/07294360.2018.1512955

Parylo, O. (2015). Connecting Attitudes Toward Teaching and Pedagogical Formation Courses: A Study of Turkish Pre-Service Teachers. Australian Journal of Teacher Education. 2015 40(5).

Pekkarinen, V., \& Hirsto, L. (2017). University Lecturers' Experiences of and Reflections on the Development of Their Pedagogical Competency. Scandinavian Journal of Educational Research, 0(0), 1-19. https://doi.org/10.1080/00313831.2016.1188148

Salikin, H., Bin-Tahir, S. Z., Kusumaningputri, R., \& Yuliandari, D. P. (2017). The Indonesian EFL Learners' Motivation in Reading. English Language Teaching, 10(5), 81. https://doi.org/10.5539/elt.v10n5p81 
Stoeber, J., Childs, J. H., Hayward, J. A., \& Feast, A. R. (2011). Passion and motivation for studying: Predicting academic engagement and burnout in university students. Educational Psychology,

Tsai, C. H., Cheng, C. H., Yeh, D. Y., \& Lin, S. Y. (2017). Can learning motivation predict learning achievement? A case study of a mobile game-based English learning approach. Education and Information Technologies, 22(5), 2159-2173. https://doi.org/10.1007/s10639-016-9542-5

Vallerand, R. J. (2012). From motivation to passion: In search of the motivational processes involved in a meaningful life. Canadian Psychology, 53(1), 42-52. https://doi.org/10.1037/a0026377

Uno, H. B. (2006). Teori Motivasi \& Pengukurannya. Gorontalo: Bumi Aksara.

Yulika, R., Rahman, U., \& Sewang, A. M. (2019). The Effect of Emotional Intelligence and Learning Motivation on Student Achievement, 39(1), 1-8. https://doi.org/10.2991/icamr18.2019.94

Zarzycka-Piskorz, E. (2016). Kahoot it or not? Can games be motivating in learning grammar? Teaching English with Technology, 16(3), 17-36. 